\title{
Temporal and spatial responses of Chironomidae (Diptera) and other benthic invertebrates to urban stormwater runoff
}

\author{
Susan E. Gresens · Kenneth T. Belt $\cdot$ \\ Jamie A. Tang · Daniel C. Gwinn • \\ Patricia A. Banks
}

Received: 22 December 2005 / Revised: 18 July 2006/ Accepted: 21 July 2006/Published online: 6 October 2006

(C) Springer Science+Business Media B.V. 2006

\begin{abstract}
In a longitudinal study of two streams whose lower reaches received unattenuated urban stormwater runoff, physical disturbance by stormflow was less important than the persistant unidentified chemical impacts of urban stormwater in limiting the distribution of Chironomidae, and Ephemeroptera, Trichoptera and Plecoptera (EPT). A hierarchical spatial analysis showed that chironomid density did not decrease from rural to urban stream reaches. Instead, the taxonomic composition of chironomid assemblages was significantly altered in urban versus rural reaches; chironomid assemblages in urban reaches exhibited higher average pollution tolerance scores. In contrast, the density of EPT was significantly lower in urban reaches. Despite higher values of stormflow tractive force in urban reaches, streambed stability tended to be greater in urban reaches. Modeling of temporal variation
\end{abstract}

Handling editor: K. Martens

S. E. Gresens $(\bowtie) \cdot$ J. A. Tang · D. C. Gwinn ·

P. A. Banks

Department of Biological Sciences, Towson

University, 8000 York Road, Towson, MD 21252,

USA

e-mail: sgresens@towson.edu

\section{K. T. Belt}

Baltimore Ecosystem Study, University of Maryland, Baltimore County, 5200 Westmoreland Boulevard, Baltimore, MD 21227, USA in chironomid density showed similar patterns in both rural and urban reaches: chironomid density had a unimodal relationship to rainfall index (RI), with highest densities at intermediate values of RI. Models of EPT density over time in rural reaches showed no significant relation to RI, and temporal variation in EPT density in urban reaches was not predictable. The abundance of fine particulate organic matter, including periphyton (FPOM), on cobbles was greater in urban reaches and showed a much greater degree of temporal variation than in rural reaches. In urban reaches, a negative relation between FPOM and RI indicated the importance of stormflow abrasion.

Keywords Chironomid - Macroinvertebrate · Urban stream · Runoff · Disturbance

\section{Introduction}

Impervious area (IA), the area of the watershed that is covered by roofs, roads and parking lots, is a hallmark of urbanization, and is widely used to quantify the degree of urban development (Schueler, 1994). Increased IA alters the hydrology of urban areas, leading to erosion, pollution and habitat destruction (Pitt et al., 1995; May et al., 1997). As the land surface loses its ability to absorb rainwater, stream discharge becomes 
highly variable as increased runoff during storms leads to short but intense floods and greater erosion and substrate disturbance. Impervious cover reduces the opportunity for soils and vegetation to filter non-point source runoff before it enters streams, and associated storm drains by-pass riparian buffers entirely. Urban stormwater runoff may carry high concentrations of road salt, as well as metals and hydrocarbons which accumulate in stream sediments (Pitt, 1995; Duke et al., 1999; Paul \& Meyer, 2001). Concentrations of sediment bound pesticides and herbicides in urban streams have been observed to exceed those in agricultural streams (Stackelberg, 1997).

Declines in the diversity of stream biota (Jones \& Clark, 1987; Steedman, 1988) have been reported to begin at a threshold value of $10-20 \%$ IA (Klein, 1979; Schueler,1994). It is difficult to identify which stressors are most important at low levels of development because stream invertebrate communities at low levels of IA are highly variable and many stressors increase simultaneously (Karr \& Chu, 1999). Biological processes such as competition, predation and recruitment can lead to large between-site differences in temporal variation of populations in unimpacted streams (Wiley et al., 1997), however changes in the physical and chemical habitat of urban streams may decrease the importance of competition and predation in structuring these benthic communities.

The goal of our study was to quantify the spatial and temporal variation of larval Chironomidae (Diptera), and other benthic invertebrates, and to determine whether these patterns were consistent with limitation of the biota by stormflow disturbance. The impact caused by low levels of watershed development can be easily masked by inherent differences between catchments, therefore "threshold" responses of streams are most effectively observed by intensive study within a catchment (Booth \& Jackson, 1997). Our study focused on two streams that traverse sharp gradients between rural and urban landuse patches. We assumed that stormwater runoff was the major source of urban impact on the streams. A hierarchical analysis was used to compare variation in invertebrate density at different spatial scales, and to detect changes in density due to the presence of urban runoff in downstream reaches. Our response variables were density of chironomid larvae (CHIR), relative abundance of Chironomidae genera, and the total density of Ephemeroptera, Plecoptera and Trichoptera (EPT) individuals. The Chironomidae were selected due to their numerical dominance in these low-order streams. The sensitivity of EPT taxa to a wide range of human impacts has led to the extensive use of EPT metrics in bioassessment (Resh \& Jackson, 1993; Thorne \& Williams, 1997). Stormflow tractive force was estimated and applied to measures of substrate composition and channel geometry to compare the degree of physical disturbance among study sites. Time series data for CHIR, EPT and periphyton biomass were analyzed to determine their responses to variation in resources, rainfall intensity and other abiotic factors over a 2-year period.

\section{Methods}

Sampling sites

We conducted a longitudinal study of two secondorder streams, Oregon Branch and Deep Run, in Baltimore County, MD. These streams were chosen because they both drain largely forested or agricultural uplands, which we refer to as "rural reaches", and then flow into sharply defined "urban reaches" which drain areas including a business park and a professional/commercial center respectively (Fig. 1). Because most of this urban development predates requirements for stormwater management, the urban reaches received unattenuated stormwater runoff. Four permanent sampling sites were established on each stream. Two sampling sites (R1 and R2) were located at riffles in the rural reach and two sites (U1 and U2) were located at riffles in the urban reach of each stream, where stormwater outfalls were present. The area of the Oregon Branch watershed, as defined by the furthest downstream site (U2) was 1,086 ha and the area of the Deep Run watershed studied was 578 ha at the corresponding site. 
Fig. 1 Location of watersheds and sampling sites, with respect to areas of high impervious cover

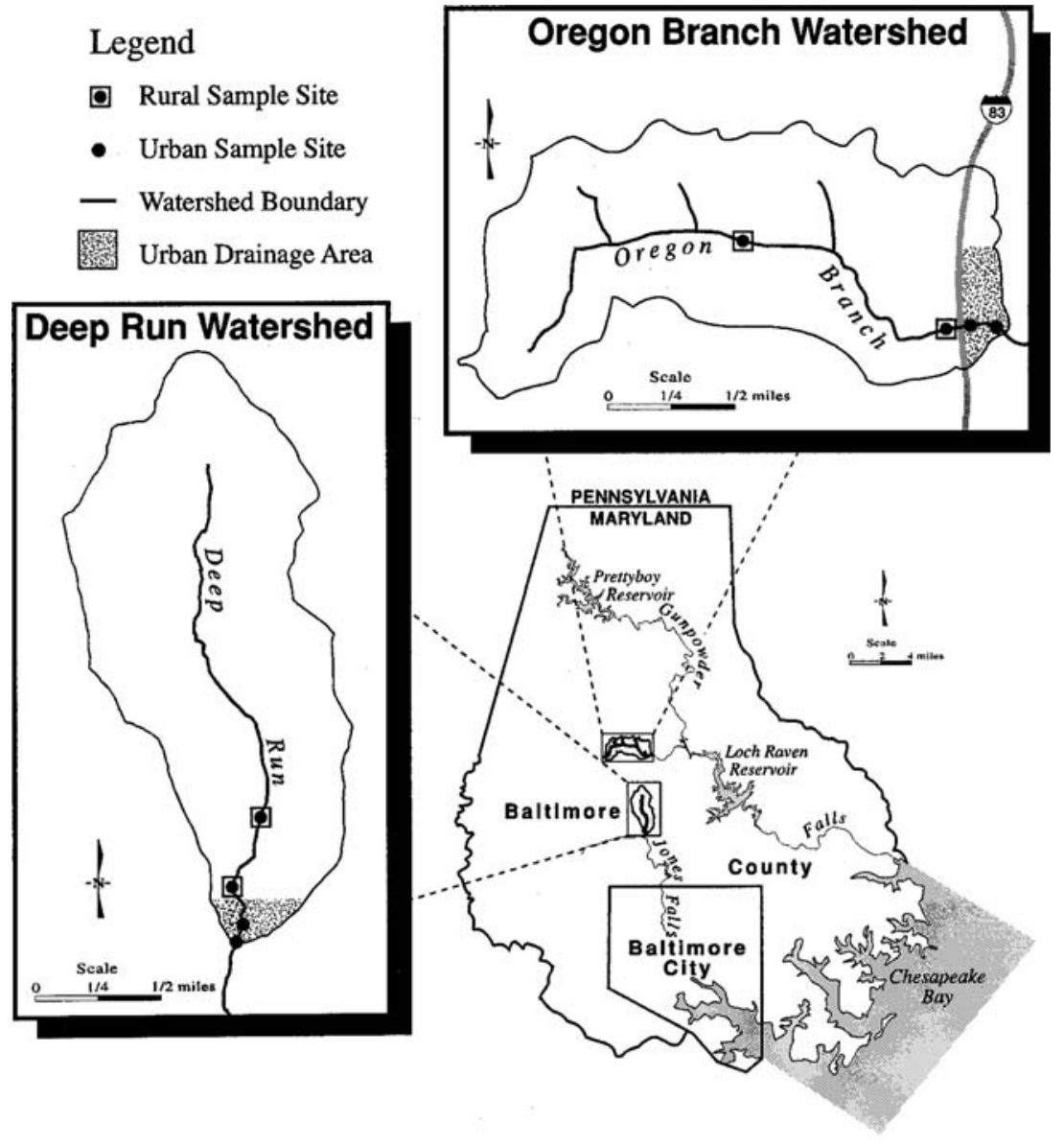

Total impervious cover (e.g., roads, parking lots, buildings) was determined using 1:6,000 photogrametric maps. Extensive field surveys confirmed that most roads and parking lots were connected to the storm drainage network. We subdivided each stream basin into local areas that drained into the immediate vicinity of each sampling station (but excluding areas draining to upstream sites). Boundaries of local drainage areas were determined using 1:7,200 topographic maps, with 2-foot contour intervals. The percent total IA was estimated for each local drainage area and also for the cumulative watershed upstream of each sampling site. To provide a complementary measure of urbanization, land use data were derived from the 1994 Land Use/Land Cover Maps $(1: 63,360)$ prepared by the Maryland Office of Planning. Watershed boundaries were digitized using USGS topographic maps
$(1: 24,000)$ and associated orthophotoquads, and reflected the distribution of stormwater conveyances as above. In addition, the width of forested riparian buffers along these streams was measured from the orthophotoquads, at $100 \mathrm{~m}$ intervals along the mainstem of each stream. Buffer width data were grouped by width class and plotted as a cumulative frequency distribution.

Sampling methods

To compare the habitat at the sampling sites we measured canopy cover and geomorphic characteristics. The slope of the bed was measured along the length of each riffle, and channel cross-sections at the riffle were used to calculate width to depth $(w / d)$ ratios for bankfull stage (Leopold et al., 1964). Pebble counts of 100 particles per riffle (Kondolf, 1997) were used to measure the size 
distributions of surficial bed sediments. Percent canopy cover was measured using a spherical densiometer, to determine if there were major differences in light availability among sites. Streamwater anion concentrations (nitrate, phosphate, sulfate and chloride) were measured at baseflow for several dates during March-April 1999, using ion chromatography (Groffman et al., 2004).

Peak stream stage during storms was recorded at each of the four sites on Oregon Branch using stage crest gauges modeled after those of the U.S. Geological Survey Water Resources Division. The gauges were read after each runoff-producing rain event (ca. $0.1 \mathrm{~cm}$ rainfall as measured by nearby manual and telemetered rain gauges), and every 2 weeks during drought periods. Rainfall data were obtained from nearby weather stations maintained by the City of Baltimore. These data were supplemented with rainfall data from NOAA weather stations at the BaltimoreWashington airport, and the Maryland Science Center, in Baltimore City (NOAA, 1996-8, NOAA, 2000). Tractive force, $\left(\mathrm{kg} / \mathrm{m}^{2}\right)$, the force applied to the stream substrate by flowing water, was used as an indicator of physical stress during storm events. Tractive force was estimated using the formula $\tau=1,000 *$ depth * slope, where 1,000 refers to the specific gravity of water $(\mathrm{kg} /$ $\left.\mathrm{m}^{3}\right)$, the depth $(\mathrm{m})$ was obtained from the crest gauges, and the water surface slope measured along the length of the riffle (Dunne \& Leopold, 1978; Cobb et al., 1992). The maximum size of a stream bed particles predicted to move during a rainstorm was derived from the following empirical relationship:

$\tau\left(\mathrm{kg} / \mathrm{m}^{2}\right)=$ diameter $(\mathrm{cm})$ of particle

between the peak value of tractive force, $\tau$ and particle size that it could move (Newbury, 1996). This estimate was then applied to a cumulative frequency distribution of sediment particle size, based on the pebble count data, to determine what percent of bed particles ought to be moved.

Epilithic invertebrates were sampled on 16 dates, at approximately monthly intervals from May 1996 to July 1998. Given our focus on chironomid larvae, sampling methods were chosen to accommodate repeated sampling of these small riffles without drastically altering the habitat, and to avoid under-sampling early instar larvae (Berg $\&$ Hellenthal, 1990). We used a $64 \mu \mathrm{m}$ mesh net for sampling benthic organisms from individual cobbles (Scrimgeor et al., 1993). Five randomly chosen cobbles were collected from each riffle. Water temperature, depth and velocity were measured at the location of each cobble. Aufwuchs was removed from the cobbles in a bucket of water, and this composite sample was subsampled for analysis of invertebrate densities. The amount of fine particulate organic material (FPOM) was estimated by collecting a subsample of this material, which had passed through a $1 \mathrm{~mm}$ sieve, onto GF/C filters for measurement of ash-free dry mass. Surface area of the sampled cobbles was measured by wrapping cobbles in aluminum foil and relating foil mass to cobble surface area (Wrona et al., 1986; Death \& Winterbourn, 1995). This allowed estimation of invertebrate density per unit substrate area. Invertebrate samples were stained with rose bengal before counting and identification at $12 x$ magnification. This sampling method yielded 200 1,000 organisms or more per sample unit, but included large numbers of early instars, which limited our ability to identify them accurately to family level. Therefore, invertebrates were generally identified to order, while Diptera were identified to family. To estimate the relative abundance of the dominant genera of chironomids at each site and date, subsamples of 50 fourth and third instar larvae were cleared, slide mounted and identified, according to Wiederholm (1986), Bode (1983) and Epler (2001). It was often difficult to distinguish larvae of Orthocladius and Cricotopus; alternatively they were placed in one of four operational taxonomic groups (OTUs) defined on the basis of structure of the mentum and lauterbourn organs, and head capsule coloration. Field-collected larvae were individually reared in the laboratory, to obtain larval/ pupal associations and determine the composition of $\mathrm{O} / \mathrm{C}$ groups. To further confirm larval identifications, all pupae included in the samples were slide-mounted in CMC-10, which afforded sufficient clearing to determine genus (allowing easy separation of Orthocladius from Cricotopus) and, in some cases, to species. 
Statistical analyses

Hierarchical ANOVA models, incorporating nested effects, are valuable for determining the spatial and temporal scales of ecological variation, and have been used to solve problems of confounding of treatment effects with spatial variability (Winer, 1971; Underwood, 1997). This analysis provides separate estimates of (1) variation among riffles nested within a reach, (2) variation between reaches within a stream (exposed to, or free from urban runoff) and (3) variation between streams. This allowed us compare variation due to runoff with a more appropriate error term (i.e., variation of riffles within a given reach type). Orthogonal contrasts were constructed a priori, to test whether densities of CHIR and EPT were greater at rural riffles than at urban riffles with densities continuing to decrease downstream within the urban reaches. Use of a nested model assumes that there are no significant interactions between the experimental factor (i.e., runoff) and the classification effects. Such an interaction would imply that the biota from different reaches within a stream had fundamentally different responses to urban runoff. Although we could not test this assumption, given the similarity in physical habitat structure, and the potential for considerable drift of biota from upstream to downstream reaches, we maintain that this would be minor in comparison to the direct effects of runoff. This assumption could cause problems if samples include different stream habitat types, different ecoregions, or if sampling spanned a great range of urbanization.

ANOVA models also assume normality and independence of the data, and homogeneity of variance among treatment levels. Log transformation of the variables CHIR and EPT provided a good fit to the ANOVA model. Because our data was collected from riffles repeatedly sampled at intervals of one month or greater, temporal autocorrelation among samples from each riffle was examined using Mantel tests (Manly, 1997), performed using PC-ORD software (McCune \& Mefford, 1999). SAS software (SAS, 1999) was used for ANOVAs and regression analyses. Barlett's test was applied to log-transformed data for
CHIR and EPT to determine whether significant heterogeneity of variances was present.

An ordination of chironomid assemblage structure across all sites was performed by nonmetric multidimensional scaling (NMS), using PC-ORD software (McCune \& Mefford, 1999). A matrix of relative euclidean distance was used (after removal of six rare genera). The best representation included three dimensions (with a final stress value of 14.5 , and Monte Carlo test with $P=0.032$ ). To determine whether chironomid assemblages in rural reaches differed significantly from those of urban reaches, randomization tests (Manly, 1997) were applied to the scores on each of the three NMS axes: within each of the 16 collecting dates, scores were randomly assigned to rural and urban reaches, differences were calculated and their sum recorded. The randomization procedure was repeated 5,000 times.

The relation of chironomid assemblage structure to water quality was examined by calculation of biotic index (BI) scores for each reach. Tolerance values for chironomid genera/species came primarily from the Maryland benthic IBI (Stribling et al., 1998) if available, otherwise, values from Ohio, Mid-Atlantic or North Carolina indices (Barbour et al., 1999) were used.

Regression models were used to explore associations between EPT, CHIR, and environmental variables, particularly those relating to rainfall and epilithic FPOM. A rainfall index (RI) was used to indicate the intensity and frequency of precipitation (i.e., potential runoff), based on the flow index of Shortreed \& Stockner (1983): $\mathrm{RI}=\Sigma\left(R_{i} / i\right)$, where $R_{i}$ equals total daily rainfall $i$ days before a sampling date, and the summation was made over the month preceding the sampling date.

\section{Results}

Landscape data

Total IA differed greatly for local drainage areas in rural versus urban reaches (Table 1). The direct local drainages for rural stream sites ranged from $0.7 \%$ to $3 \%$ IA; in contrast, direct local 


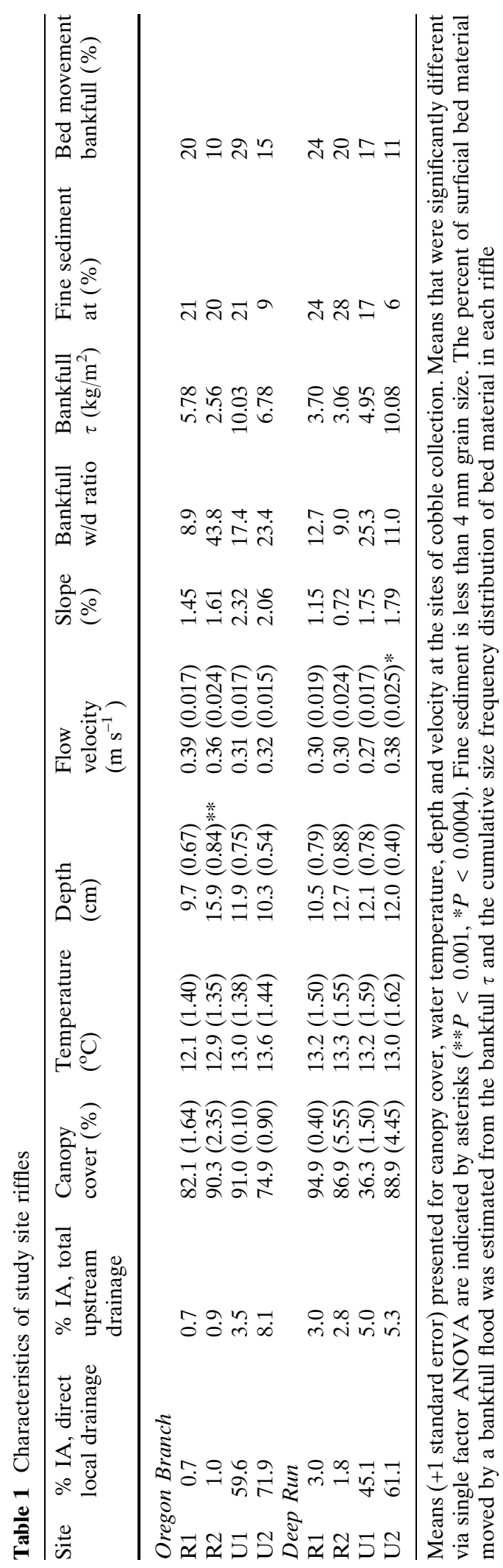

drainage for urban sites ranged from $60 \%$ to $70 \%$ IA. However, when the entire upstream watershed was considered, the overall IA remained low. At the downstream end of the urban reaches, total IA was only $8.1 \%$ for Oregon Branch and $5.3 \%$ for Deep Run.

Forests covered $23 \%$ of both watersheds (Table 2). Agriculture (primarily hayfields and pasture) was the dominant land use (46\%) in the Oregon Branch watershed, whereas low-density residential development was the major land use $(45 \%)$ in the Deep Run watershed. The nature of low-density residential development differed sharply between the watersheds: most houses around Deep Run occupied forested lots, but large lawns were common along Oregon Branch. Commercial, industrial and institutional areas occupied a greater area in the Oregon Branch watershed $(12 \%)$ than in the Deep Run watershed (5\%). Oregon Branch had less extensive forested buffers along the stream channel (Fig. 2). Over half of the riparian buffer along Oregon Branch was less than $32 \mathrm{~m}$ wide whereas the median buffer width was $158 \mathrm{~m}$ for Deep Run. Although the developed reaches of Deep Run lacked riparian buffers, this was minor compared to the extensive forested buffer in the upper watershed.

Most sample sites had canopy cover ranging from $75 \%$ to $95 \%$, except for Deep Run site U1, where canopy cover was $36 \%$ (Table 1 ). Stream temperature ranged annually from $4.7^{\circ} \mathrm{C}$ to $19.5^{\circ} \mathrm{C}$ on Oregon Branch, and from $3.6^{\circ} \mathrm{C}$ to $20.7^{\circ} \mathrm{C}$ on Deep Run. Average stream temperature at the times of sampling did not differ significantly among sites (Table 1). Little difference in the concentrations of nitrate, phosphate, sulfate or chloride ions was observed between rural and urban sub-watersheds, or between watersheds (Table 3). Mean depth was significantly greater at Oregon Branch, site R2, and mean flow velocity was greater at Deep Run, U2 (Table 1).

Bankfull width/depth ratios showed no consistent pattern of change as the two streams flowed into urban areas. The urban riffles had higher slopes than rural riffles, and riffles on Oregon Br. had steeper slopes than on Deep Run (Table 1). Surficial sediments at rural sites contained more fine particles than urban sites (Table 1); this 
Table 2 Land use characteristics of rural and urban reaches of Oregon Branch and Deep Run. "Rural" reach includes sampling sites R1 and R2

\begin{tabular}{llllll}
\hline Land use categories & $\begin{array}{l}\text { Low density } \\
\text { residential }\end{array}$ & $\begin{array}{l}\text { Medium/high density } \\
\text { residential }\end{array}$ & $\begin{array}{l}\text { Commercial/industrial/ } \\
\text { institutional }\end{array}$ & $\begin{array}{l}\text { Open urban } \\
\text { (golf course) }\end{array}$ & $\begin{array}{l}\text { Agriculture } \\
\text { Forest }\end{array}$ \\
\hline Oregon Branch & & & & & \\
Rural & 19.60 & 0 & 1.28 & 0 & 52.81 \\
Total & 17.29 & 0 & 12.40 & 0.76 & 46.44 \\
Deep Run & & & 3.74 & 10.66 & 26.31 \\
Rural & 47.09 & 1.13 & 5.16 & 10.08 & 13.48 \\
Total & 44.87 & 3.52 & & 23.12 \\
\hline
\end{tabular}

The "total" watershed includes the entire area that drains to the furthest downstream site, U2. Land use is measured as percent of total watershed area. Urban land use classifications included Low-density residential (less than 2 detached dwelling units per acre), Medium-density residential (2-8 dwellings per acre) and High-density residential (over 8 dwellings per acre), plus commercial and institutional land uses

Fig. 2 Cumulative frequency distribution of riparian buffer width classes for Oregon Branch (diamonds) and Deep Run (triangles)

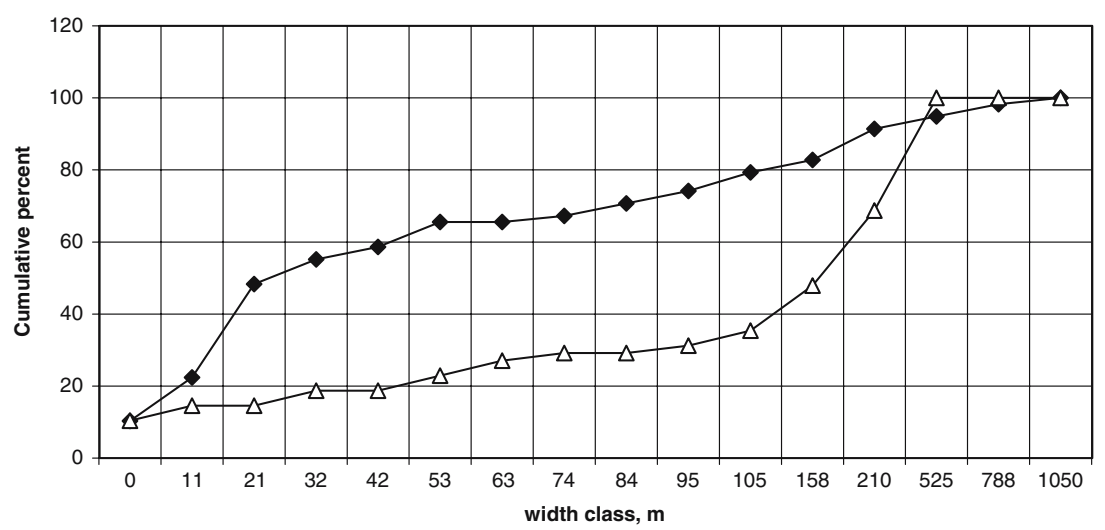

Table 3 Mean $( \pm$ s.e.) concentration of anions (phosphate, nitrate, sulfate and chloride) in streamwater at baseflow, March/April 1999

\begin{tabular}{lllll}
\hline Site & $\mathrm{PO}_{4}^{-3}(\mathrm{mg} / \mathrm{l})$ & $\mathrm{NO}_{3}^{-1}(\mathrm{mg} / \mathrm{l})$ & $\mathrm{SO}_{4}^{-2}(\mathrm{mg} / \mathrm{l})$ & $\mathrm{Cl}^{-1}(\mathrm{mg} / \mathrm{l})$ \\
\hline \multicolumn{2}{l}{ Oregon Branch } & & & \\
$\mathrm{R} 1$ & $0.0085(0.0043)$ & $8.13(0.33)$ & $10.29(0.82)$ & $44.8(7.25)$ \\
$\mathrm{U} 2$ & $0.0055(0.0012)$ & $8.12(0.09)$ & $12.64(0.51)$ & $62.5(7.25)$ \\
Deep & & & & \\
$\mathrm{R} 1$ & & & & \\
$\mathrm{U} 2$ & $0.0045(0.0008)$ & $8.48(0.35)$ & $11.05(1.56)$ & $52.7(5.69)$ \\
\hline
\end{tabular}

pattern was especially marked at site Deep Run site R2, where $53 \%$ of bed particles were less than $16 \mathrm{~mm}$ diameter (Fig. 3). Fine sediments were defined as particles less than $4 \mathrm{~mm}$, based on a break in the size-frequency distribution of particles at each riffle. The proportion of fine sediment ranged from $20 \%$ to $28 \%$ at upstream sites, and ranged from $6 \%$ to $21 \%$ at the downstream sites. When the data for both streams were pooled based on the outcome of a heterogeneity chisquared analysis (Zar, 1999), the proportion of fine sediments was found to be significantly greater at upstream sites $\left(\chi^{2}=6.41,0.01<P<0.025\right)$.

Peak tractive force per rain event on Oregon Branch (Fig. 4) was estimated from measurements of maximum stage during storm flow. Maximum stage for a given storm varied greatly between the upstream and downstream sites. Runoff from smaller rainstorms typically produced no measurable change in stage at site R1 but did cause increases in stage at the downstream sites. A rise in stage was recorded 41 times 

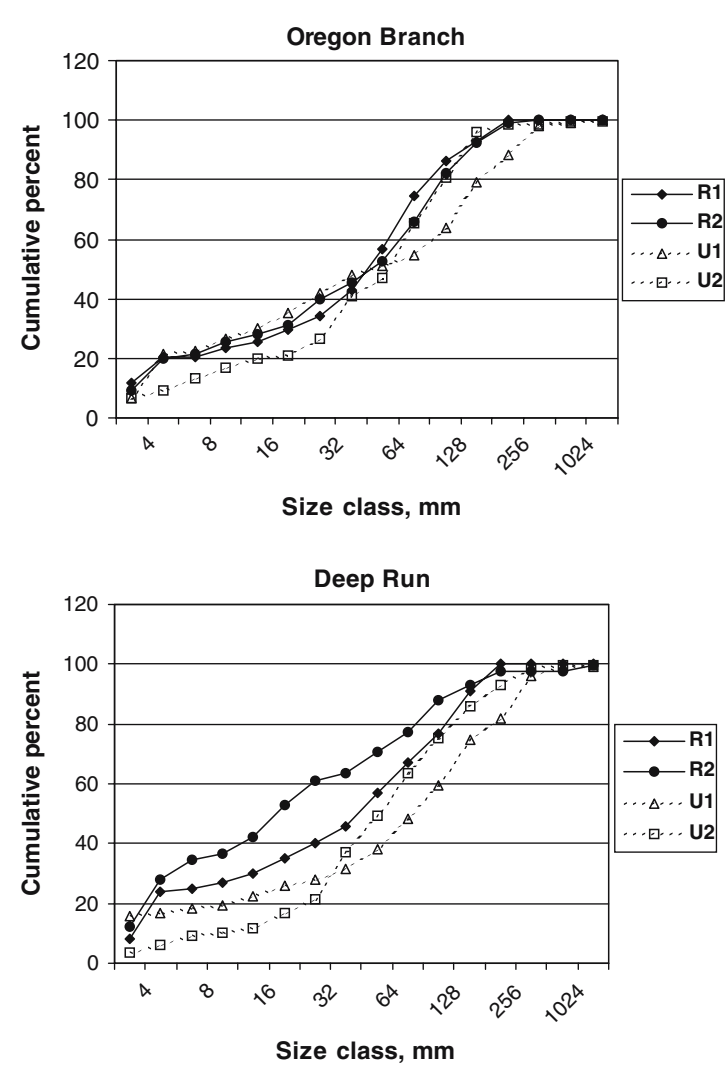

Fig. 3 Cumulative frequency distributions for size of stream bed particles in study sites riffles

at R1, 47 times at R2, 61 times at $\mathrm{U} 1$ and 80 times at U2. When peak tractive force was averaged for the 31 rainfall events that produced a measurable increase in stream depth at all sites, tractive force was lowest at R1 $\left(3.2 \mathrm{~kg} / \mathrm{m}^{2}\right)$ and increased downstream. The highest mean values of tractive force occurred at sites U1 $\left(10.2 \mathrm{~kg} / \mathrm{m}^{2}\right)$ and $\mathrm{U} 2$ $\left(9.1 \mathrm{~kg} / \mathrm{m}^{2}\right)$. Tractive force at bankfull stage was estimated at all sites using cross-sectional area and slope data (Table 1) and the largest estimates of tractive force did occur in the urban reaches. However, estimates of bed stability, i.e., the percent of bed material moved during a bankfull flood, tended to be lower in the urban reaches (Table 1), reflecting variation in both the width/ depth ratio and the abundance of fine sediment particles among sites.

Benthic fauna

Diptera, particularly Chironomidae, numerically dominated the invertebrate community (Table 4); larval Tipulidae were also common and their distribution was correlated with that of chironomids $(r=0.563, P<0.0001)$. Macroinvertebrate densities and the abundance of FPOM were both generally higher in Oregon Branch (Table 4), although mean densities of Plecoptera tended to be higher in Deep Run. This may reflect the differences in extent of riparian buffers, and the balance of agricultural versus forested landcover. Nevertheless, nested ANOVA did not detect significant differences in either EPT or chironomid density between streams (Table 5). Coleoptera (Elmidae and Psephenidae) density was correlated with EPT density $(r=0.496, P \leq 0.0001)$. The
Fig. 4 Shear stress estimates $(\tau)$ for storms registering a rise in stage at all Oregon Branch sites

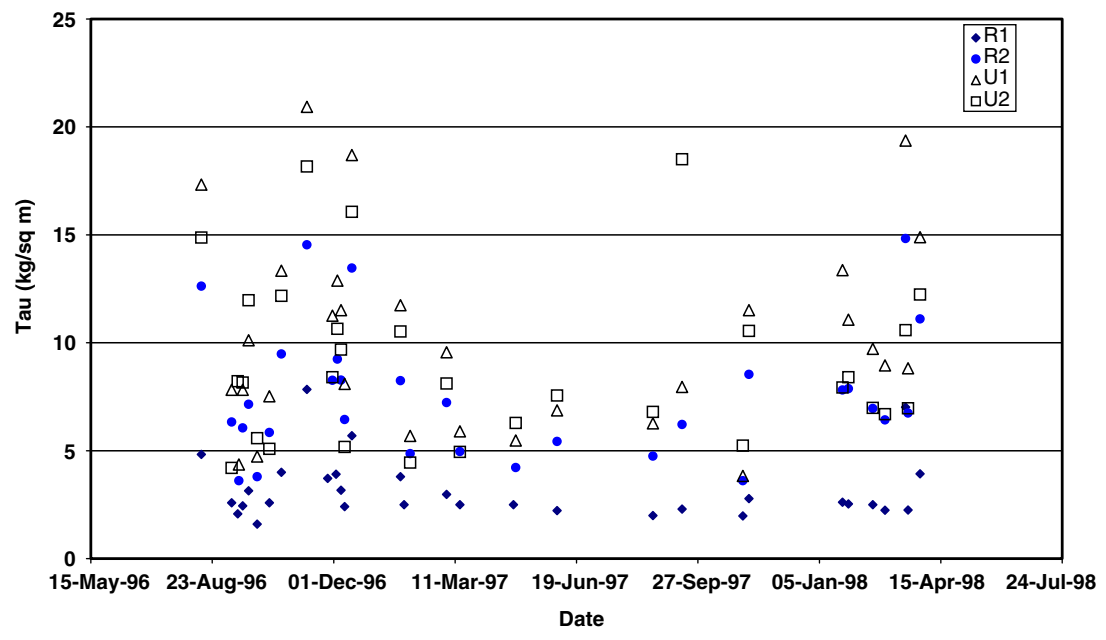




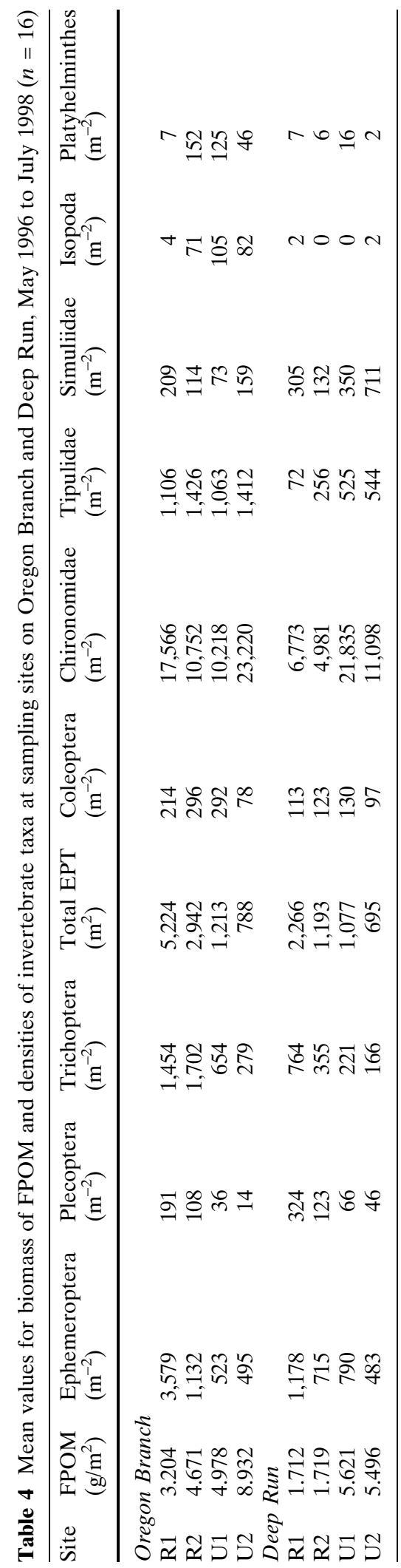

Table 5 Nested ANOVAs of densities of two groups of benthic invertebrates

\begin{tabular}{lrrrl}
\hline Source & df & SS & \multicolumn{1}{l}{$F$} & $P$ \\
\hline EPT density (log-transformed) & & & & \\
Stream & 1 & 6.479 & 0.32 & 0.6280 \\
Reach (within stream) & 2 & 40.333 & 12.15 & 0.0200 \\
Riffle (within reach, stream) & 4 & 6.640 & 3.02 & 0.0204 \\
Within riffle & 119 & 65.307 & & \\
Chironomidae larvae (log-transformed data) & & \\
Stream (within stream) & 1 & 6.639 & 1.28 & 0.3750 \\
Reach (with & 2 & 10.360 & 1.92 & 0.2606 \\
Riffle (within reach, stream) & 4 & 10.806 & 3.02 & 0.0206 \\
Within riffle & 119 & 106.496 & & \\
\hline
\end{tabular}

periphyton at all sites was dominated by diatoms, which were a conspicuous component of FPOM, in addition to fine detritus. Macroscopic tufts of the diatom Melosira often developed during dry weather. The green alga Cladophora was present at one upstream and two downstream sites, but filaments rarely grew longer than 1-2 mm.

Thirty four taxa of chironomids were identified from collections of larvae, but 6 were very rare and were not included in the NMS ordination. The most diverse OTU was "O/C1" which included $O$. Orthocladius obumbratus, O. O. mallochi, and Cricotopus triannulatus. "O/C2" was predominantly Cricotopus triannulatus, common in both summer and winter samples. Cricotopus tremulus corresponded to "O/C3", though variation in form of the mentum and in head capsule pigmentation sometimes made it difficult to separate $C$. tremulus from $C$. triannulatus. $\mathrm{O} / \mathrm{C} 4$ was dominated by $O$. Orthocladius dorenus, common at many suburban sites, and included a small number of $O$. Orthocladius nigritus. Orthocladius O. obumbratus pupae were only observed in March collections, whereas pupae of various Cricotopus spp. were collected throughout spring, summer and fall periods. Pupae of Neozavrelia were dominant in both streams, whereas Sublettea was uncommon. Pupal collections were also valuable in identification of Eukiefferiella species; E. pseudomontana was confined largely to the most upstream reach (R1) of Oregon Branch. Eukiefferiella c.f. rectangularis gr. sp., (according to Bode, 1983), and E. claripennis gr. larvae were more widely distributed, and E. rectangularis gr. larvae were particularly common in both rural 
and urban reaches of Deep Run. Independent collections of pupae and pupal exuviae from these sites suggest that larval E. rectangularis may more closely resemble the European E. clypeata gr. in the pupal stage.

\section{Analysis of spatial pattern}

The data for both EPT and CHIR satisfied the assumptions of the ANOVA model. No temporal autocorrelation was detected in densities of EPT from a given site at intervals of 1 month or more; for all 8 sites subject to Mantel tests, $P>0.167$. Likewise, homogeneity of variance of EPT among all sites was accepted (Bartletts test, $0.5<P<0.75)$. In addition, we compared the magnitude of temporal variation of EPT in urban riffles versus rural riffles. The ratio of pooled mean squares (MS) for urban riffles vs. rural riffles $\quad\left(\mathrm{MS}_{\text {pooled,urban }} / \mathrm{MS}_{\text {pooled,rural }}=1.32\right)$ when compared with the appropriate $F$ statistic (Underwood, 1997) was not significant $(0.1<P<0.25)$, indicating that variability in EPT over time was similar at rural and urban sites. Similarly, there was no temporal autocorrelation in CHIR density within each site; none of the Mantel tests for any of the sites was significant $(P>0.10)$. Bartletts test also indicated homogeneous variances among all 8 study sites $(0.5<P<0.75)$.

Density of EPT showed significant heterogeneity between rural/urban reaches, relative to the variability of riffles within each reach type (Table 5). Significant variation also existed among riffles within a given reach type. In contrast, there was no significant variation in EPT between the two streams. Tests of the orthogonal contrast $\mu_{\mathrm{R} 1}=\mu_{\mathrm{R} 2}>\mu_{\mathrm{U} 1}>\mu_{\mathrm{U} 2}$ supported our prediction of continuing decrease in EPT (Fig. 5) within urban reaches $(F=6.85, P<0.001$ for both streams). In contrast, chironomid density showed no significant heterogeneity among streams, and no heterogeneity between rural/urban reaches within streams (Table 5). However, there was significant variability among riffles within a reach type, relative to the amount of within-riffle variation over time. No consistent pattern of increase or decrease in CHIR was observed along the land use gradient for either
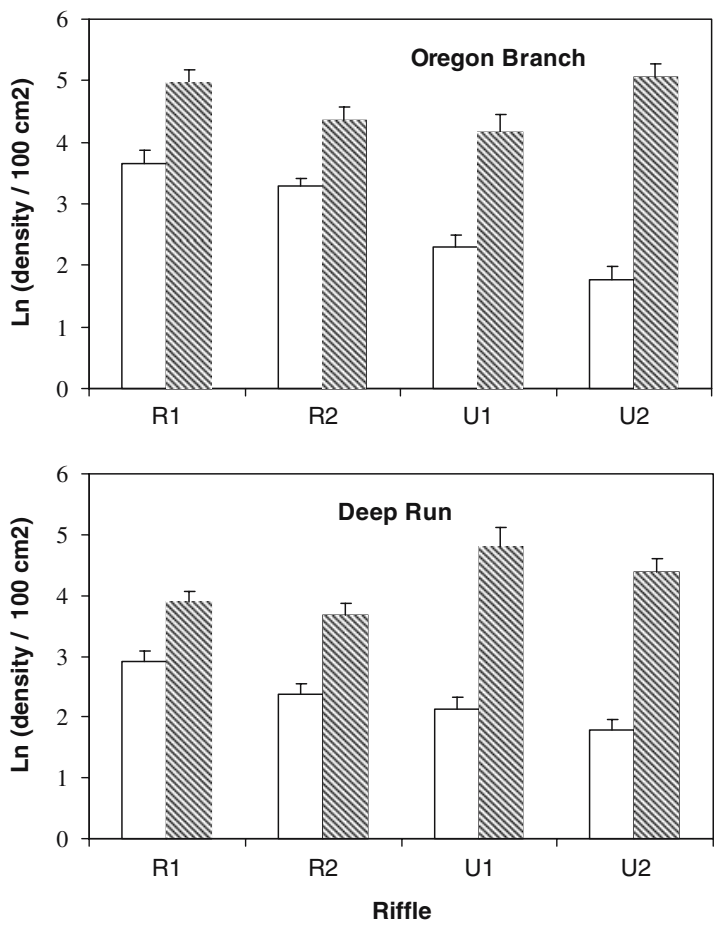

Fig. 5 Mean densities (+1 standard error) of EPT (open bars) and Chironomidae (hatched bars) at study sites

stream (Fig. 5). Increased temporal variation of CHIR in urban reaches was marginally significant, with $\mathrm{MS}_{\text {pooled,urban }} / \mathrm{MS}_{\text {pooled,rural }}$ corresponding to $F=1.65$ and $0.025<P<0.05$. This hypothesis differed from that of homogeneity of variance among all riffles (Bartletts test), because temporal variation was compared between 2 groups of sites, instead of among all 8 sites.

Although total density of chironomid larvae did not differ significantly between rural and urban reaches, chironomid assemblage structure clearly varied with the degree of urbanization of the stream reach. Three axes were retained in the NMS ordination and the amount of variance explained, in terms of the correlation of ordination distances with distances among the original samples, was greatest for axis 3 , with $R^{2}=0.430$. Axes 1 and 2 were associated with smaller components of variation: for axis $2, R^{2}=0.146$, and for axis 1 , $R^{2}=0.184$.

Axis 3 distinguished rural and urban reaches most clearly (Fig. 6). Urban sites had significantly lower scores on axis 3 (randomization tests: axis $3, P=0.0002)$. Correlations of site scores with 
Fig. 6 Sample scores and chironomid taxa scores from NMS ordination of samples collected on 16 dates, at the 4 study reaches ( = "riffle"). Riffle codes: $1-4=$ reaches on Oregon Branch, from upstream to downstream; 5$8=$ reaches on Deep Run from upstream to downstream. All solid symbols represent urban reaches. Riffles 8 and $9=$ additional urban reaches on Oregon Branch and Deep Run, respectively. Taxa codes are as listed in Table 6

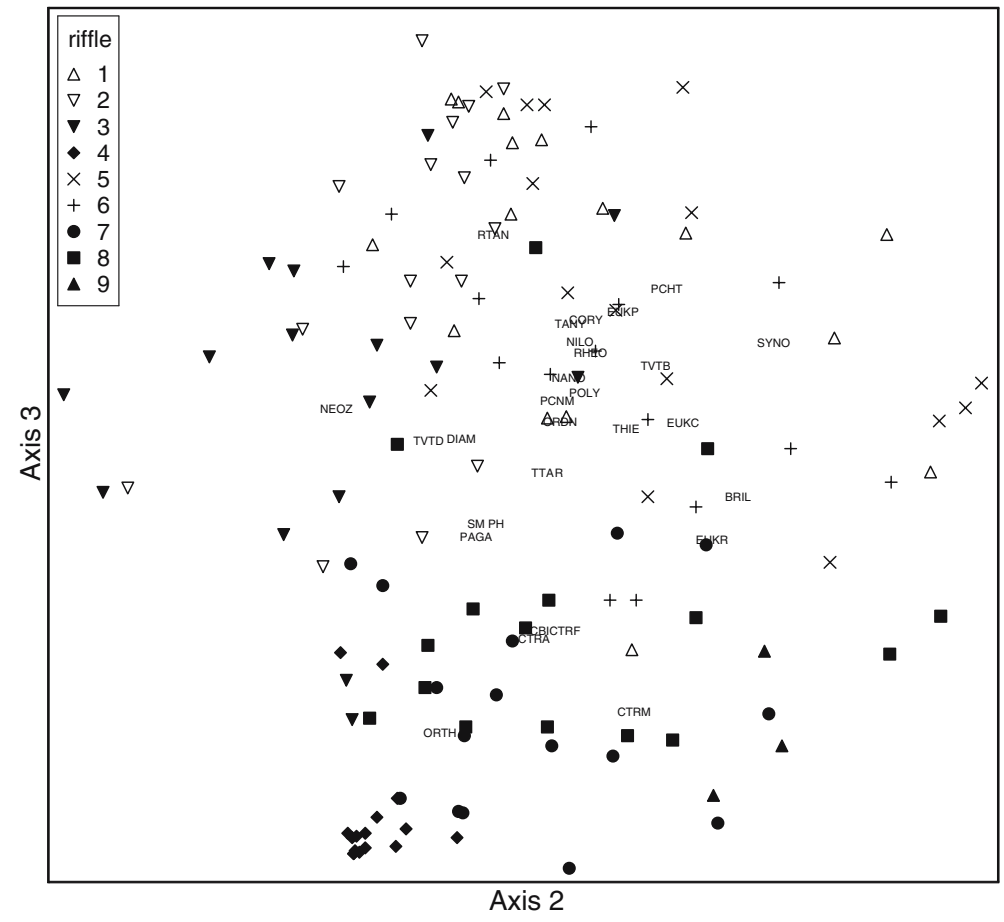

relative abundance of taxa (Table 6) were used to interpret the components of variation captured by the ordination axes. Cricotopus species and "O/C1" (e.g., O. Orthocladius obumbratus), dominant in urban reaches, had negative correlations with axis 3 , whereas taxa restricted to rural reaches (e.g Corynoneura sp., Eukiefferiella pseudomontana gr., Rheotanytarsus sp., Thienemanimyia gr. and Tvetenia bavarica) had the largest positive correlations with axis 3 . Although urban sites also had significantly lower scores on axis 2 (randomization test, $P=0.0008$ ) the
Table 6 Correlations (Kendall's Tau) of chironomid taxa with ordination axes two and three, produced by NMS of a matrix on relative euclidean distances. Only taxa with correlations on these axes greater than 0.10 in absolute value are shown

\begin{tabular}{|c|c|c|c|}
\hline Taxon & Code & Axis 2 & Axis 3 \\
\hline Thienemannimyia gr. sp. & TANY & 0.064 & 0.298 \\
\hline Diamesa sp. & DIAM & -0.123 & -0.017 \\
\hline Pagastia sp. & PAGA & 0.032 & -0.131 \\
\hline Brillia sp. & BRIL & 0.189 & -0.020 \\
\hline Corynoneura sp. & CORY & .180 & 0.263 \\
\hline Cricotopus bicinctus & $\mathrm{CBIC}$ & -0.038 & -0.282 \\
\hline C. tremulus "O/C3" & CTRM & 0.218 & -0.275 \\
\hline C. triannulatus " $\mathrm{O} / \mathrm{C} 2 "$ & CTRA & 0.030 & -0.256 \\
\hline C. trifascia & CTRF & 0.033 & -0.183 \\
\hline Eukiefferiella claripennis gr. sp. & EUKC & 0.165 & 0.064 \\
\hline E. pseudomontana gr. sp. & EUKP & 0.130 & 0.222 \\
\hline E. rectangularis gr. sp. & EUKR & 0.486 & -0.114 \\
\hline Orthocladius/Cricotopus "O/C1" & ORTH & -0.267 & -0.679 \\
\hline Parachaetocladius sp. & PCHT & 0.139 & 0.131 \\
\hline Synorthocladius sp. & SYNO & 0.170 & 0.101 \\
\hline Thienemanniella sp. & THIE & 0.191 & 0.115 \\
\hline Tvetenia bavarica & TVET & 0.135 & 0.238 \\
\hline Polypedilum spp. & POLY & 0.069 & 0.123 \\
\hline Neozavrelia sp. & NEOZ & -0.375 & 0.127 \\
\hline Rheotanytarsus spp. & RTAN & -0.105 & 0.621 \\
\hline Tanytarsus spp. & TTAR & 0.102 & 0.009 \\
\hline
\end{tabular}


pattern was not as clear, and appeared to contrast only Oregon Branch site U1 (associated with Neozavrelia and Diamesa) with Deep Run site R1 (associated with E. rectangularis gr., C. tremulus and Thienemanniella). There was no significant difference in urban versus rural site scores on axis 1, which may instead reflect seasonal changes, given a significant correlation to water temperature $(r=-0.5002, P<0.05)$.

Average assemblage tolerance scores, calculated from the totals for chironomid taxa at each reach, reflected the local concentration of stormwater outfalls in each stream. Along Oregon Branch, average tolerance scores changed little among the rural sites $(\mathrm{R} 1=4.27, \mathrm{R} 2=4.22)$, which were potentially impacted by runoff from crossings of small local roads (2 road crossings above R1 and one additional crossing above R2). The upper urban reach, U1, with tolerance score $=4.27$, was exposed to runoff from an interstate highway and one large culvert draining part of the business park. At the most urban reach, $\mathrm{U} 2$, which received stormwater runoff from the business park via six storm gutters, 12 drain pipes and one paved tributary, the tolerance score (5.90) increased further. The rural reaches of Deep Run were exposed to road runoff from one road crossing (R2), and had average tolerance values of 5.14 (R1) and 5.23 (R2). Deep Run site $\mathrm{U} 1$ received runoff from one pipe and a large culvert draining parking lots, and had a tolerance value of 6.25 , whereas site U2, which was impacted further by runoff from a major road crossing, had a slightly lower tolerance value (5.91).

Modeling temporal variation

Multiple regression models were used to determine the ability of sampling date (Month), RI, and FPOM (a surrogate for food abundance) to predict temporal variation in EPT and CHIR. Densities of EPT increased over the summer to an annual peak in September, with low densities in winter and a smaller increase in density in February to March. To simplify modeling of EPT, values of Month were coded to begin the year in January. Densities of CHIR rose sharply by May to an annual peak in June, and declined gradually until the following spring, thus in modeling CHIR, values of Month were coded to begin the year in May. Quadratic terms for Month were included to improve fit of the model.

It was necessary to model EPT separately for rural and urban reaches (Table 7) because none of the predictor variables were significant with the urban data. For EPT in rural reaches, $R^{2}$ was $39 \%$, and variables relating to Month and FPOM were highly significant (Table 7). Both linear and quadratic terms for Month were significant, reflecting the gradual increase in EPT density during spring and summer, and the decline in density during fall and winter. Only in rural streams was there a positive association between FPOM and density of EPT. RI showed no significant relation to EPT in either reach type.

Table 7 Multiple regression models predicting EPT using sampling date (MONTH), an index of rainfall intensity (RI), and FPOM

\begin{tabular}{llclr}
\hline Variable & Model & Parameter & Standard error & $P$ \\
\hline Intercept & Rural & 1.6482 & 0.6413 & 0.0129 \\
\multirow{3}{*}{ Month } & Urban & 0.9808 & 0.7615 & 0.2028 \\
& Rural & 0.6613 & 0.1595 & $\mathbf{0 . 0 0 0 1}$ \\
Month $^{2}$ & Urban & 0.3088 & 0.2045 & 0.1364 \\
& Rural & -0.0427 & 0.0109 & $\mathbf{0 . 0 0 0 3}$ \\
RI & Urban & -0.0194 & 0.0140 & 0.1699 \\
& Rural & 0.0259 & 0.7502 & 0.9726 \\
FPOM & Urban & -0.7307 & 0.8458 & 0.3912 \\
& Rural & 0.5504 & 0.1375 & $\mathbf{0 . 0 0 0 2}$ \\
& Urban & -0.1193 & 0.2078 & 0.5682 \\
\hline
\end{tabular}

Variables EPT and FPOM were log-transformed Data from rural reaches and urban reaches were modeled separately. $P$-values that were significant after sequential Bonferroni correction (Holm, 1979) are listed in bold 
Table 8 Multiple regression model predicting CHIR density in combined urban and rural data

\begin{tabular}{lrlr}
\hline Variable & Parameter & Standard error & \multicolumn{1}{l}{$P$} \\
\hline Intercept & 5.2891 & 0.2756 & $<0.0001$ \\
Month & -0.1694 & 0.0258 & $<0.0001$ \\
RI & 2.4401 & 0.5900 & $<0.0001$ \\
RI $^{2}$ & -1.3690 & 0.3424 & 0.0001 \\
FPOM & 0.7149 & 0.1050 & $<0.0001$ \\
\hline
\end{tabular}

Variables CHIR and FPOM were log-transformed

In contrast, a single model for CHIR at all sites performed as well $\left(R^{2}=39 \%\right)$ as separate models for rural and urban reaches, and the combined model is presented (Table 8). All four predictors were significant. Density declined linearly throughout the year, following a sharp increase during April/May. Chironomid density increased with abundance of FPOM. RI had a non-linear relationship with CHIR: during extended periods of dry weather, chironomid density increased with increasing $\mathrm{RI}$, but the negative term for $\mathrm{RI}^{2}$ indicates that at high rainfall intensity CHIR declined (Table 8).

Epilithic FPOM, reflecting both periphyton and fine detritus, was also modeled separately by reach type, because only the urban model was significant $\left(R^{2}=35 \%\right)$. Seasonal variation in canopy cover exerted a strong negative influence on FPOM $\quad\left(b_{\text {canopy }}=-0.0853, \quad P<0.0001\right)$ whereas RI had a weaker negative influence $\left(b_{\mathrm{RI}}=-0.294, \quad P=0.033\right)$. Mean biomass of FPOM was greater in urban reaches $\left(6.39 \mathrm{~g} / \mathrm{m}^{2}\right.$, s.e. $=0.484)$ than in rural reaches $\left(2.80 \mathrm{~g} / \mathrm{m}^{2}\right.$, s.e. $=0.261)$, and in winter this difference $(5.41 \mathrm{~g} /$ $\left.\mathrm{m}^{2}\right)$ was greater than in summer $\left(2.36 \mathrm{~g} / \mathrm{m}^{2}\right)$. A formal test of mean FPOM biomass, was not carried out, because of highly significant heterogeneity of variation among riffles.

\section{Discussion}

Studies linking urban stream condition with IA have focused primarily on stormwater runoff and physical disturbance as the primary stressor of the benthos, while acknowledging that chemical degradation may also be associated with runoff (Schueler, 1994; Booth et al., 2004; Moore \&
Palmer, 2005). Our results indicate that the impacts of low-level watershed imperviousness on macroinvertebrates were not primarily due to physical disturbance and streambed instability during storm events. Instead, shifts in the composition of macroinvertebrate assemblages suggested that urban stormwater runoff lead to persistant degradation of the chemical quality of the habitat. The significant shift in taxonomic composition of chironomid assemblages suggests persistent effects of stormwater, probably due to toxic compounds and/or nutrients adsorbed to deposited sediment (Pitt, 1995), although we were not able to measure these directly. Pratt et al. (1981) also concluded that the effects of urban runoff on stream benthos were mediated via toxic compounds accumulated in the sediments.

Hierarchical analyses of spatial variation showed that the densities of EPT and Chironomidae responded very differently to urban stormwater runoff. There were significant declines in EPT density in urban reaches of both streams. Declines in EPT taxonomic richness in response to increasing watershed IA are consistently reported (Garie \& McIntosh, 1986; Jones \& Clark, 1987; Morse et al., 2003; Roy et al., 2003; Gray, 2004; Moore \& Palmer, 2005). In contrast, the density of Chironomidae did not vary significantly between rural and urban reaches in the present study. If stormflow scour were an important mechanism for disturbance, chironomid larvae should have been vulnerable since we specifically sampled chironomids from cobble surfaces.

Chironomid assemblage composition did change significantly in the presence of urban stormwater runoff. Thirty-four chironomid taxa were recorded in this study, but this represents only a fraction of total chironomid richness, since we sampled only cobble microhabitats, and species preferring sand, leaf packs or wood were greatly undersampled. The reaches with the greatest concentration of stormwater outfalls (Oregon Branch U2 and Deep Run U1) were dominated by several species of Cricotopus: $C$. triannulatus (Macquart), C. tremulus (Linnaeus), and $C$. bicinctus (Meigen), and to a lesser extent C. trifascia (Edwards). Larvae of several of these species were difficult to reliably distinguish from 
those of Orthocladius O. obumbratus (Johannsen), which was also common in the urban reaches, although it appeared to be univoltine (with a spring emergence), whereas the Cricotopus species appeared to be bivoltine. Jones \& Clark (1987) also found that urbanization of watersheds in the Virginia piedmont lead to an increase the relative abundance of Cricotopus and Orthocladius, even though the total density of the benthos did not change. In the North Carolina piedmont, $C$. bicinctus was most abundant in an agricultural stream, but remained a dominant species in their urban stream (Lenat \& Crawford, 1994).

Sensitive chironomid genera, whose distributions were most strongly limited by urbanization (ranked in order of the magnitude of their scores on ordination axis 3) included Rheotanytarus sp., Thienemannimyia gr. sp., Corynoneura sp., E. pseudomontana gr. sp., and Tvetenia bavarica (Thienemann). Lenat \& Crawford (1994) also found that Tanytarsus sp. and Rheotanytarsus sp. were dominant in a forested stream, but uncommon in an urban stream; Rheotanytarsus larvae, which are filtering collectors, were most abundant in their agricultural stream. Other chironomids dominant in their forested stream, and charactersistic of our rural reaches included Parametriocnemus sp., Thienemanniella spp. and Polypedilum sp.

Although the entire family Chironomidae has been treated as moderately tolerant to highly tolerant (Hilsenhoff, 1988) different chironomid genera vary widely in the value they receive for tolerance to organic enrichment (Barbour et al., 1999). Given the higher FPOM/periphyton abundance in urban reaches, the observed increase in average tolerance to enrichment exhibited by chironomid assemblages was not surprising. However some genera/species appear to differ in their tolerance to organic enrichment versus other toxic components of urban stormwater runoff. Maryland benthic-IBI tolerance values (Stribling et al., 1998) for some of our "rural" taxa appeared too high: e.g., Rheotanytarsus, (tolerance value, $\mathrm{TV},=6)$ and Tanytarsus $(\mathrm{TV}=6)$; on the other hand, Sympotthastia $(\mathrm{TV}=2)$ appeared moderately tolerant of urban runoff, and maintained high densities in Deep Run, especially at site U2.
Thienemannimyia gr sp. (subfamily Tanypodinae) did not receive a MD B-IBI tolerance value, but we consider them very sensitive to urban runoff. In addition, certain common genera include species with noticeably different tolerance values, which poses a potential bias. Within the genus Orthocladius $(\mathrm{TV}=6)$, O. obumbratus was strongly associated with urban runoff, whereas $O$. dorenus (Roback) (i.e., O/C4) though widely distributed in our study streams, was distinctly less common in reaches with urban runoff. Orthocladius nigritus (Malloch) (also in $\mathrm{O} / \mathrm{C} 4$ ) was confirmed only from larvae collected in rural reaches and other local forested streams. Likewise, the MD B-IBI rates the genus Eukiefferiella highly tolerant $(\mathrm{TV}=8)$, while we consider E. pseudomontana gr.sp. highly sensitive to urban runoff, E. claripennis gr.sp. to be moderately tolerant, and E. rectangularis gr. to be very tolerant. For some genera, intermediate tolerance values may reflect wide variation in the tolerances of individual species.

Although urban stormwater runoff created a greater potential for physical disturbance, predicted bed stability was actually higher in three of the four urban riffles. The higher peaks in tractive force resulted in armoring of the bed within riffles, where fine particles were depleted compared to rural riffles of similar slope (Fig. 3, Table 1). In later stages of urbanization, the increased flow competence of streams is predicted to result in the removal of fine sediments, as has been demonstrated in streams in the Vancouver, B.C., area, 20 years after development of their catchments (Finkenbine et al., 2000). However the length of time generally required for this change in sediment to occur is not known (Finkenbine et al., 2000). Bed armoring as a result of urbanization is not always observed: Pizzuto et al. (2000) found little decrease in fine sediment and no evidence of bed armoring in urban streams in Pennsylvania. Although fines were depleted in the riffles of urban reaches of Oregon Branch and Deep Run, the runs and pools surrounding all sites nevertheless held large quantities of sand. Wolman \& Schick (1967) mapped the channel of Oregon Branch directly below our study sites, and recorded large sand and silt bars from recent development; they predicted this sediment would be removed 
within seven years, though extensive deposits still remain.

Disturbance from stormflow should act as an intermittent stress on macroinvertebrates, and should increase temporal variation in density. The regression model of EPT density in rural reaches showed that EPT density was strongly associated with MONTH and FPOM, but not with RI (Table 7). This was not surprising, given the lower values of stormflow tractive force on the rural reaches of Oregon Branch. Densities of both invertebrate groups showed large fluctuations in density and size of individual organisms, concordant at all sites, during the course of the year: because the highest densities were dominated by early instars, MONTH was interpreted as reflecting seasonal recruitment. Invertebrate drift from less-impacted upstream reaches should provide colonists to downstream urban reaches, and allow rapid recovery between storms, as observed in non-urban streams (Matthei et al., 1996). Despite the potential for recolonization from upstream, no model of temporal fluctuations in the low density of EPT in urban reaches was significant, suggesting the habitat in urban reaches was persistently poor for EPT.

The temporal dynamics of chironomid density were similar in rural and urban reaches. The regression model showed that chironomid density was strongly influenced by seasonal recruitment (MONTH) and by FPOM. Limitation by stormflow scour was expected to yield a linear negative relationship between density and RI. However, chironomid density exhibited a significant nonlinear response to RI (Table 5). The highest chironomid densities tended to occur at intermediate values of RI, whereas lower densities were observed following either extended dry spells, or periods of high rainfall. Studies focusing on diversity of stream benthos, have found that the total density of benthic invertebrates declined with increasing disturbance (Death \& Winterbourn, 1995; McCabe \& Gotelli, 2000), or that density shows no relationship to intensity of flood disturbance (Townsend et al., 1997).

The unimodal response of chironomid density to rainfall (RI) suggests that both low flow and high flow conditions are stressful to chironomid populations. Even if the streambed is largely stable, stormflow may abrade organisms clinging to stable substrates and may limit the periphyton food resources of invertebrates (Death, 2002). The cobble-dwelling chironomid larvae that we sampled should have been particularly vulnerable to abrasion, since they construct their retreats on the upper surfaces of cobbles, and are not as mobile as most EPT species. However, the larger and/or embedded rocks in a more stable streambed may provide some refuge for chironomids, at least. Following very large floods in local urban streams (June 2006), a thin layer of periphyton and numerous chironomid retreats could still be found on the sheltered faces of scattered large rocks (Gresens, personal observation). Extended low-flow periods may also be stressful if low flow limits nutrient uptake by and production of biofilm/periphyton. Low quantity and poor quality of food has been demonstrated to limit survival and growth of early instar chironomids in the laboratory (Vos et al., 2000).

FPOM is of interest as an indicator of abrasion of epilithic surfaces, but more importantly, this mixture of detritus, bacteria, fungi, diatoms and other algae, represents a major food resource for many macroinvertebrates. The Chironomidae, Ephemeroptera and Coleoptera in these streams overwhelmingly represented collector-gatherer and scraper functional feeding groups. Hydropsychidae were the most common Trichoptera, but Glossosomatidae were conspicuous grazers in rural reaches. In rural reaches temporal variation in FPOM abundance showed no relationship to rainfall or canopy; instead, FPOM may have been limited by grazing, given the higher densities of large-bodied grazing invertebrates (e.g., Ephemerellidae, Heptageniidae and Glossomatidae) in rural reaches. EPT density in rural reaches appeared to track FPOM abundance. In trout streams with stable flow, Glossosoma reduced both algal biomass and the growth of chironomid larvae, whereas supression of Glossosoma populations lead to increased abundance of periphyton, grazers and filter-feeders in several streams (Kohler \& Wiley, 1997). Grazing trichoptera also decreased periphyton and chironomids in forested California streams (Wootton et al., 1996) and in laboratory microcosms (Anderson et al., 1999). An experimental study employing nutrient 
diffusing substrates at sites R1 and U2 on Oregon Branch, and sites R1 and U1 on Deep Run (Lawrence \& Gresens, 2004) found a highly significant response of chironomids and other collector-gatherers to nutrient amendments, in the absence of any significant nutrient-response by periphyton, suggesting that phosphorus limited algal-grazer interactions at all sites except Deep Run U1. These two lines of evidence suggest that, during summer, grazers may be more important than soluble nutrients in limiting biofilm/periphyton accrual, in the rural reaches of these streams. This interpretation is supported by the results of Bourassa \& Cattaneo (1998) who found that periphyton were limited by grazing (not light or nutrients) in streams spanning a range of phosphate concentrations from $1 \mu \mathrm{g} / \mathrm{l}$ to $34 \mu \mathrm{g} / \mathrm{l}$. Phosphate data (Table 3) place our sites in the lower end of this range.

Temporal variation in FPOM in urban reaches did conform to our expectations for material abraded by intermittent stormflow disturbance. Mean biomass and standard error of FPOM was higher in urban stream reaches. The regression model for FPOM indicated that FPOM did have a significant linear negative relationship to RI; but the effect of canopy cover was even stronger, emphasizing the importance of seasonal variation in light (i.e., leaf-out and leaf fall) in limiting the algal component of FPOM in urban reaches.

Many studies have sought to identify a threshold for degradation of urban streams, and to determine at what degree of imperviousness it occurs, but the occurrence of thresholds is still in debate (Walsh et al., 2005). Perception of a threshold will be influenced by variation in the distribution of study sites, e.g., in amount of stormwater piped directly to streams within a catchment (Taylor, 2004; Walsh, 2004), in local geology (Booth et al., 2004) and in the degree to which streams have attained a new geomorphologic equilibrium (Finkenbine et al., 2000). We have demonstrated responses of EPT density and chironomid composition at 5-8\% IA, in two streams where storm drains created a strong aquatic-terrestrial linkage. Additional studies have detected urban impacts from $5 \%$ to $10 \%$ IA (Booth \& Jackson, 1997; Morse et al., 2003; Ourso \& Frenzel, 2003; Moore \& Palmer, 2005). We conclude that at such low levels of IA, chemical constituents in stormwater runoff may be more important than physical disturbance as a cause of decline in the biological integrity of streams.

Acknowledgements We would like to thank the following: M. Roberge for land use/land cover analysis; W. Stack for access to City of Baltimore rainfall data; P. Groffman and the Baltimore Ecosystem Study for nutrient analyses, and two anonymous reviewers for their helpful comments. We are grateful to additional students who volunteered in lab and field: H. O'Hara, N. Forand, B. Anuszkiewicz, S. Boller, and J. Urbanski.

\section{References}

Anderson, E. L., E. B. Welch, J. M. Jacoby, G. M. Schimek \& R. R. Horner, 1999. Periphyton removal related to phosphorus and grazer biomass level. Freshwater Biology 41: 633-651.

Barbour, M. T., J. Gerritsen, B. D. Snyder \& J. B. Stribling, 1999. Rapid Bioassessment Protocols for Use in Streams and Wadeable Rivers: Periphyton, Benthic Macroinvertebrates and Fish. 2nd edn. EPA 841-B99-002. U.S. Environmental Protection Agency; Office of Water; Washington, DC.

Berg, M. B. \& R. A. Hellenthal, 1990. Data variability and the use of Chironomids in environmental studies: the standard error of the midge. In Davis, W.S. (ed.), Proceedings of the 1990 Midwest Pollution Control Biologists Meeting. U.S. Environmental Protection Agency Region V, Environmental Sciences Division, Chicago, IL. EPA-905-9-9-/005: 1-8.

Bode, R. W., 1983. Larvae of North American Eukiefferiella and Tvetenia (Diptera: Chironomidae). Bulletin No. 452. New York State Museum. The State Education Department, Albany, New York.

Booth, D. B. \& C. R. Jackson, 1997. Urbanization of aquatic systems: degradation thresholds, stormwater detention, and the limits of mitigation. Journal of the American Water Resources Association 33: 1077-1090.

Booth, D. B., J. R. Karr, S. Schauman, C. P. Konrad., S. A. Morley, M. G. Larson \& S. J. Burges, 2004. Reviving urban streams: land use, hydrology, biology and human behavior. Journal of the American Water Resources Association 40: 1351-1364.

Bourassa, N. \& A. Cattaneo, 1998. Control of periphyton biomass in Laurentian streams (Quebec). Journal of the North American Benthological Society 17: 420429.

Cobb, D. G., T. D. Galloway \& J. F. Flannagan, 1992. Effects of discharge and substrate stability on density and species composition of stream insects. Canadian Journal of Fisheries and Aquatic Sciences 49: 17881795.

Death, R., 2002. Predicting invertebrate diversity from disturbance regimes in forest streams. Oikos 97: 1830 . 
Death, R. \& M. Winterbourn, 1995. Diversity patterns in stream benthic invertebrate communities: the influence of habitat stability. Ecology 76: 1446-1460.

Duke, D. L., T. S. Lo \& M. W. Turner, 1999. Chemical constituents in storm flow vs. dry weather discharges in California storm water conveyances. Journal of the American Water Resources Association 35: 821-836.

Dunne, T. \& L. B. Leopold, 1978. Water in Environmental Planning. W.H. Freeman \& Co., San Francisco, CA.

Epler, J. H., 2001. Identification Manual for the Larval Chironomidae (Diptera) of North and South Carolina. Special Publication SJ2001-SP13. North Carolina Department of Environment and Natural Resources. Division of Water Quality.

Finkenbine, J. K., J. W. Atwater \& D. S. Mavinic, 2000. Stream health after urbanization. Journal of the American Water Resources Association 36: 11491160.

Garie, H. L. \& A. McIntosh, 1986. Distribution of benthic macroinvertebrates in a stream exposed to urban runoff. Water Resources Bulletin 22: 447-455.

Gray, L., 2004. Changes in water quality and macroinvertebrate communities resulting from urban stormflows in the Provo River, Utah, U.S.A. Hydrobiologia 518: 33-46.

Groffman, P. M., N. L. Law, K. T. Belt, L. E. Band \& G. T. Fisher, 2004. Nitrogen fluxes and retention in urban watershed ecosystems. Ecosystems 7: 393-403.

Hilsenhoff, W. L., 1988. Rapid field assessment of organic pollution with a family-level biotic index. Journal of the North American Benthological Society 7: 65-68.

Holm, S., 1979. A simple sequentially rejective multiple test procedure. Scandinavian Journal of Statistics 6: 65-70.

Jones, R. C. \& C. C. Clark, 1987. Impact of watershed urbanization on stream insect communities. Water Resources Bulletin 23: 1047-1055.

Karr, J. R. \& E. W. Chu, 1999. Restoring Life in Running Waters. Island Press, Washington, D.C.

Klein, R. D., 1979. Urbanization and stream quality impairment. Water Resources Bulletin 15: 948-963.

Kohler, S. L. \& M. J. Wiley, 1997. Pathogen outbreaks reveal large-scale effects of competition in stream communities. Ecology 78: 2164-2176.

Kondolf, G. M., 1997. Application of the pebble count: notes on purpose, method and variants. Journal of the American Water Resources Association 33: 79-87.

Lawrence, J. W. \& S. E. Gresens, 2004. Foodweb response to nutrient enrichment in rural and urban streams. Journal of Freshwater Ecology 19: 375-385.

Lenat, D. R. \& J. K. Crawford, 1994. Effects of land use on water quality and aquatic biota of three North Carolina piedmont streams. Hydrobiologia 294: 185-199.

Leopold, L. B., M. G. Wolman \& J.P. Miller, 1964. Fluvial Processes in Geomorphology, 1995 republication by Dover Publications, New York, NY.

Manly, B. F. J., 1997. Randomization, Bootstrapping and Monte Carlo Methods in Biology. 2nd edn. Chapman \& Hall, London.
Matthaei, C. D., U. Uehlinger, E. I. Meyer \& A. Frutiger, 1996. Recolonization by benthic invertebrates after experimental disturbance in a Swiss prealpine river. Freshwater Biology 35: 233-248.

May C. W., R. R. Horner, J. R. Karr, B. W. Mar \& E. B. Welch, 1997. Effects of urbanization on small streams in the Puget Sound lowland ecoregion. Watershed Protection Techniques 2: 483-494.

McCabe, D. J. \& N. J. Gottelli, 2000. Effects of disturbance frequency, intensity, and area on assemblages of stream invertebrates. Oecologia 124: 270-279.

McCune, B. \& M. J. Mefford, 1999. PC-ORD. Multivariate Analysis of Ecological Data. Version 4. MJM Software Design. Gleneden Beach, OR.

Moore, A. A.,\& M. A. Palmer, 2005. Invertebrate biodiversity in agricultural and urban headwater streams: implications for conservation and management. Ecological Applications 15: 1169-1177.

Morse, C. C., A. D. Huryn \& C. Cronan, 2003. Impervious surface area as a predictor of the effects of urbanization on stream insect communities in Maine, U.S.A. Environmental Monitoring and Assessment 89: 95127.

National Oceanic and Atmospheric Administration (NOAA). 1996-1998. Local Climatological Data, Monthly Summary. National Climatic Data Center, Asheville, NC.

Newbury, R. W., 1996. Dynamics of flow. In Hauer, F. R. \& G. A. Lamberti (eds), Methods in Stream Ecology. Academic Press, San Diego, CA.

Ourso, R. T. \& S. A. Frenzel, 2003. Identification of linear and threshold responses in streams along a gradient of urbanization in Anchorage, Alaska. Hydrobiologia 501: $117-131$.

Paul, M. J. \& J. L. Meyer, 2001. Streams in the urban landscape. Annual Review of Ecology and Systematics 32: 333-365.

Pitt, R. E., 1995. Biological effects of urban runoff discharges. In E. E. Herricks, (ed.), Stormwater Runoff and Receiving Systems: Impact, Monitoring and Assessment. Lewis Publ. Boca Raton, Florida, 127162.

Pitt, R., R. Field, R. Lalor \& M. Brown, 1995. Urban stormwater toxic pollutants: assessment, sources and treatability Water Environment Research 67: 260275.

Pizzuto, J. E., W. C. Hession \& M. McBride, 2000. Comparing gravel-bed rivers in paired and rural catchments of southeastern Pennsylvania. Geology 28: 7982.

Pratt, J. M., R. A. Coler \& P. J. Godfrey, 1981. Ecological effects of urban stormwater runoff on benthic macroinvertebrates inhabiting the Green River, Massachusetts. Hydrobiologia 83: 29-42.

Resh, V. H. \& J. K. Jackson, 1993. Rapid assessment approaches to biomonitoring using benthic macroinvertebrates. In Rosenberg, D. M. \& V. H. Resh, (eds), Freshwater Biomonitoring and Benthic Macroinvertebrates. Chapman \& Hall, New York, 195-233. 
Roy, A. H., A. D. Rosemond, M. J. Paul, D. S. Leigh \& J. B. Wallace, 2003. Stream macroinvertebrate response to catchment urbanization (Georgia, U.S.A.). Freshwater Biology 48: 329-346.

SAS Institute Inc., 1999. SAS/STAT User's Guide, Version 8. SAS Institute Inc., Cary, NC.

Schueler, T., 1994. The importance of imperviousness. Watershed Protection Techniques 1: 100-111.

Scrimgeor, G. J., J. M. Culp \& N. E. Glozier, 1993. An improved technique for sampling lotic invertebrates. Hydrobiologia 254: 65-71.

Shortreed, K. S. \& J. G. Stockner, 1983. Periphyton biomass and species composition in a coastal rainforest stream in British Columbia: effects of environmental changes caused by logging. Canadian Journal of Fisheries and Aquatic Sciences 40: 1887-1895.

Stackelberg, P. E., 1997. Presence and distribution of chlorinated organic compounds in streambed sediments, New Jersey. Journal of the American Water Resources Association 33: 271-284.

Steedman, R. J., 1988. Modification and assessment of an index of biotic integrity to quantify stream quality in southern Ontario. Canadian Journal of Fisheries and Aquatic Sciences 45: 492-501.

Stribling, J. B., B. K. Jessup, J. S. White, D. Boward \& M. Hurd, 1998. Development of a benthic index of biotic integrity for Maryland streams. Report No. CBWP-MANTA-EA-98-3. Maryland Department of Natural Resources, Annapolis, MD.

Taylor, S. L., S. C. Roberts, C. J. Walsh \& B. E. Hatt, 2004. Catchment urbanization and increased benthic algal biomass in streams: linking mechanisms to management. Freshwater Biology 49: 835-851.

Thorne, R. S. J. \& P. Williams, 1997. The response of benthic macroinvertebrates to pollution in developing countries: a multimetric system of bioassessment. Freshwater Biology 37: 671-686.

Townsend, C. R., M. R. Scarsbrook \& S. Doledec, 1997. The intermediate disturbance hypothesis, refugia and biodiversity in streams. Limnology and Oceanography 42: 938-949.
Underwood, A. J., 1997. Experiments in Ecology: their Logical Design and Interpretation Using Analysis of Variance. Cambridge University Press, Cambridge, UK.

Vos, J. H., M. A. G. Ooijevaar, J. F. Postma \& W. Admiraal, 2000. Interaction between food availability and food quality during growth of early instar chironomid larvae. Journal of the North American Benthological Society 19: 158-168.

Walsh, C. J., 2004. Protection of in-stream biota from urban impacts: minimize catchment imperviousness or improve drainage design? Marine and Freshwater Research 55: 317-326.

Walsh, C. J., A. H. Roy, J. W. Feminella, P. D. Cottingham, P. M. Groffman \& R. P. Morgan, 2005. The urban stream syndrome: current knowledge and the search for a cure. Journal of the North American Benthological Society 24: 706-723.

Wiederholm, T. (ed.), 1986. Chironomidae of the Holarctic Region; Keys and diagnoses. Part 2. Pupae. Entomologica Scandinavica Supplement No. 28, Sandby, Sweden.

Wiley, M. J., S. L. Kohler \& P. W. Seelbach, 1997. Reconciling landscape and local views of aquatic communities: lessons from Michigan trout streams. Freshwater Biology 37: 133-148.

Winer, B. J., 1971. Statistical Principles in Experimental Design. McGraw-Hill, New York.

Wolman, M. G. \& A. P. Schick, 1967. Effects of construction on fluvial sediment, urban and suburban areas of Maryland. Water Resources Research 3: 451464.

Wootton, J. T., M. S. Parker \& M. E. Power, 1996. Effects of disturbance on river food webs. Science 273: 15581561.

Wrona, F. J., P. Calow, I. Ford, D. J. Baird \& L. Maltby, 1986. Estimating the abundance of stone-dwelling organisms. Canadian Journal of Fisheries and Aquatic Sciences 43: 2025- 2035.

Zar J. H., 1999. Biostatistical Analysis, 4th edn. Prentice Hall, Upper Saddle River, NJ. 